\title{
Стан показників фізичного розвитку студентів спеціальності «Правоохоронна діяльність»
}

\author{
Марина Гресь, Костянтин Пацалюк
}

Національний університет фізичного виховання і спорту України, Київ, Україна

Анотація. Фізичний розвиток завжди відображає стан здоров'я людини і є одним із його показників. Юнацький вік - це особливий етап в індивідуальному розвитку організму людини. Мета. Оцінити показники фізичного розвитку студентів - майбутніх правоохоронців як основи побудови програми занять професійно-прикладної спрямованості з використанням засобів оздоровчого фітнесу. Методи. Аналіз та узагальнення спеціальної науковометодичної літератури, провідного вітчизняного та зарубіжного досвіду, документальних матеріалів, антропометричні методи дослідження (біоелектричний імпеданс), методи математичної статистики. Результати. Отримані середньогрупові результати довжини і маси тіла у юнаків та дівчат знаходяться в межах вікових норм, серед досліджуваного контингенту відсутні особи з надлишковою масою тіла у обох статевих групах. Обхватні розміри тіла вказують на гармонійну статуру та відсутність будь-яких відхилень від фрізіологічної норми. Порівняльний аналіз тотальних розмірів тіла вказує на статистично значущу різницю $(p<0,05)$ між статевими групами, що є закономірним з огляду на вікову категорію іспитованих. Середньостатистичні показники вісцерального жиру у юнаків та дівчат знаходяться в межах фізіологічної норми, середньогрупові показники м'язового та кісткового компонентів у юнаків та кісткового компоненту у дівчат знаходяться нижче фрізіологічної норми. Отримані результати будуть використані під час розробки програми занять просресійно-прикладної спрямованості з використанням засобів кросфіту.

Ключові слова: фізичний розвиток, професійно-прикладна фрізична підготовка, оздоровчий фотнес.

\section{Maryna Hres, Kostiantyn Patsaliuk}

\section{THE STATE OF PHYSICAL DEVELOPMENT INDICES IN STUDENTS OF THE «LAW ENFORCEMENT» SPECIALTY}

Abstract. Physical development always reflects the state of human health and is one of its indices. Adolescence is a special stage in the individual development of the human body. Objective. Assess the indices of physical development of students - future law enforcement officers as a basis for designing a program of professional and applied orientation with the use of health-related fitness means. Methods. Analysis and generalization of special scientific and methodical literature, leading domestic and foreign experience, documentary materials, anthropometric research methods (bioelectric impedance), methods of mathematical statistics. Results. The obtained average group results of body length and weight in boys and girls are within the age norms, among the studied contingent there are no persons with excess body weight in both sex groups. Circumferential body size indicates a harmonious physique and the absence of any deviations from the physiological norm. Comparative analysis of total body size indicates a statistically significant difference $(p<0.05)$ between the sex groups, which is natural given the age category of the subjects. The statistically average values of visceral fat in boys and girls are within the physiological norm, the average group values of muscle and bone components in boys and bone component in girls are below the physiological norm. The obtained results will be used during the development of the program of professional and applied orientation with the use of crossfit means. Keywords: physical development, professional-applied physical training, health-related fitness.

Hres M., Patsaliuk K. The state of physical development indices in students of the «Law Enforcement» specialty. Theory and Methods of Physical education and sports. 2021: 1: 24-29

DOI: 10.32652/tmfvs.2021.1.24-29
Вступ. Вимоги до громадської безпеки у всьому світі за останні роки значно зросли. Значний ріст злочинності та насильства вимагає від фахівців правоохоронних органів удосконалення службової підготовки [3]. Діяльність у цій сорері характеризується значними психоемоційними і фізичними навантаженнями, а також постійним ризиком для життя [5]. Тому службова підготовка фахівців правоохоронних органів розглядається як важлива складова системи навчання та потужний резерв підвищення ефективності поліцейської діяльності [3]. До складових службової підготовки слід віднести тактичну, вогневу, фізичну, функціональну, а також загальнопрофрільну підготовку [5].

Аналіз наукової літератури свідчить, що фізичний розвиток завжди відображає стан здоров'я людини і $\epsilon$ одним із його об'єктивних показників [11, 14]. У студентської молоді показники фізичного розвитку, з одного боку, характеризують відповідність статистичним нормам його біологічного віку, з іншого боку, розкривають його морфологічний стан в конкретний час. Юнацький вік являє собою особливий, переломний етап в індивідуальному розвитку організму людини. у 18-19 років відбувається соціальне становлення особистості [6]. Відомо, що остаточне біологічне фрормування організму в цьому віці ще не закінчене й знання його особливостей дозволяє розробити методи цілеспрямованого впливу для досягнення гармонійного розвитку організму й збереження здоров'я молодих людей $[6,12]$.

Дослідники вказують на значні можливості оздоровчо-рекреаційної рухової активності у покращенні показників фізичного стану [1, 2, 4, 13]. 3 огляду на важливість урахування вихідних показників фрізичного стану студентів під час побудови програми занять професійно-прикладної спрямованості для майбутніх фрахівців правоохоронної діяльності доцільним 
$€$ оцінка стану показників фрізичного розвитку, що обумовило актуальність проведених досліджень [3, 4, 7, 8].

Дослідження виконано відповідно до плану НДР НУФВСУ на 20212025 рр. за темою «Теоретичні та технологічнізасади оздоровчо-рекреаційної рухової активності та здорового способу життя різних груп населення» (номер держреєстрації 0121U107534).

Мета дослідження - оцінити показники фізичного розвитку студентів - майбутніх правоохоронців як основи побудови програми занять професійно-прикладної спрямованості з використанням засобів оздоровчого фотнесу.

Методи та організація дослідження. У дослідженні брали участь 259 студентів, з них 114 юнаків та 145 дівчат, які здобувають вищу освіту за напрямом «Правоохоронна діяльність». Дослідження проводили на базі Житомирського державного технологічного університету. Студенти були задіяні у педагогічному експерименті добровільно за письмовою згодою на оприлюднення їхніх особистих даних під час розгляду та висвітлення результатів дослідження.

Теоретичний аналіз науково-методичної літератури, документальних матеріалів, узагальнення вітчизняного та зарубіжного досвіду в галузі фізичного виховання студентської молоді дозволили визначити актуальність дослідження, уточнити і конкретизувати мету, завдання і спрямованість педагогічних експериментів. 3 метою дослідження фрізичного розвитку використовували стандартні антропометричні методи. У дослідженні використовували діагностичне обладнання Tanita, яке базується на біоелектричному імпедансному аналізі (BIA) складу тіла (метод заснований на вимірюванні біоелектричного опору тканин організму). Композиційний склад тіла фрракціонували на жировий компонент, м'язовий, кістковий, вміст води. У роботі застосовано статистичні методи дослідження: аналіз даних, отриманих у процесі педагогічного експерименту, що передбачав первинний аналіз отриманих емпіричних показників із використанням описової статистики, вибіркового методу; оці- нювання узгодженості отриманих даних із законом нормального розподілу із використанням критерію згоди Шапіро-Уїлка; визначення статистично значущих відмінностей між вибірками здійснювали на основі параметричних та непараметричних критеріїв на рівні значущості $\alpha=0,05(p<0,05)$. У дослідженні емпіричні дані, які підпорядковувались нормальному закону розподілу, представлено у вигляді середнього значення й стандартного відхилення $(x ; \mathrm{S})$, а інші - у вигляді медіани та 25 і 75-го персентиля (Me; $25 \% ; 75 \%)[9,10]$. Використання цих методів дозволило провести обробку емпіричних даних, сприяло їх інтерпретації, формулюванню висновків. Систематизацію матеріалу та первинну математичну обробку виконували із використанням програмних пакетів
MS Excel (Microsoft, CШA), Statistica 8.0 (StatSoft, США).

Результати дослідження та їх обговорення. 3 метою розробки програми, спрямованої на розвиток професійно-прикладних фрізичних якостей майбутніх фрахівців правоохоронної діяльності, було проведено повну характеристику фрізичного розвитку студентської молоді. Отримані середньостатистичні результати юнаків і дівчат представлено в таблиці 1.

Відом0, що від розмірів тіла залежать інтенсивність обмінних процесів та активність фрізіологічних фрункцій. Інфрормація про взаємозв'язки між функцією та розміром дуже важлива для наукових досліджень. Вона дає можливість інтерпретувати різницю між обстежуваним контингентом, а також порівнювати індивіду-

Т а б л и ц я 1. Показники фрізичного розвитку обстежених студентів $(\mathrm{n}=259)$

\begin{tabular}{|c|c|c|c|c|c|c|}
\hline Показники & $\bar{x}$ & S & Me & $25 \%$ & $75 \%$ & $V, \%$ \\
\hline \multicolumn{7}{|c|}{ Юнаки $(n=114)$} \\
\hline Вік, років & 18,2 & 0,88 & 18,0 & 17,0 & 19,0 & 4,8 \\
\hline Довжина тіла, см & 177,0 & 6,91 & 177,5 & 174,7 & 182,5 & 3,9 \\
\hline Маса тіла, кг & 66,7 & 8,39 & 67,8 & 62,7 & 71,8 & 12,6 \\
\hline ОГК, См & 90,3 & 6,72 & 91,8 & 88,0 & 94,9 & 7,4 \\
\hline Обхват плеча, см & 29,1 & 3,12 & 29,2 & 27,0 & 32,0 & 10,7 \\
\hline Обхват талії, см & 74,6 & 6,00 & 75,0 & 72,0 & 78,0 & 8,0 \\
\hline Обхват таза, см & 92,5 & 7,78 & 93,3 & 89,7 & 97,7 & 8,4 \\
\hline Обхват стегна, см & 50,2 & 5,55 & 50,0 & 47,0 & 53,8 & 11,0 \\
\hline Динамометрія кистьова правої руки, кг & 42,3 & 9,03 & 42,0 & 39,5 & 46,2 & 21,4 \\
\hline Динамометрія кистьова лівої руки, кг & 37,3 & 8,35 & 38,8 & 32,7 & 41,2 & 22,3 \\
\hline \multicolumn{7}{|c|}{ Дівчата $(n=145)$} \\
\hline Вік, років & 18,4 & 1,11 & 19,0 & 17,0 & 19,0 & 6,0 \\
\hline Довжина тіла, см & 167,4 & 5,07 & 167,0 & 165,0 & 170,0 & 3,0 \\
\hline Маса тіла, кг & 55,4 & 5,79 & 56,9 & 50,4 & 59,7 & 10,5 \\
\hline ОГК, см & 81,5 & 5,25 & 81,0 & 78,0 & 84,0 & 6,4 \\
\hline Обхват плеча, см & 25,1 & 2,53 & 25,0 & 23,0 & 27,0 & 10,1 \\
\hline Обхват талії, см & 65,0 & 4,11 & 65,0 & 62,0 & 67,0 & 6,3 \\
\hline Обхват таза, см & 91,8 & 5,30 & 92,0 & 88,0 & 95,0 & 5,8 \\
\hline Обхват стегна, см & 51,2 & 3,84 & 51,0 & 49,0 & 54,0 & 7,5 \\
\hline Динамометрія кистьова правої руки, кг & 30,4 & 3,88 & 30,0 & 28,0 & 33,0 & 12,8 \\
\hline Динамометрія кистьова лівої руки, кг & 25,8 & 5,36 & 26,0 & 22,0 & 29,0 & 20,7 \\
\hline
\end{tabular}


Т а б л и ц я 2. Розподіл юнаків та дівчат за рівнями розвитку динамометрії кисті та абсолютної сили м'язів тулуба, \%, $(n=259)$

\begin{tabular}{|c|c|c|c|}
\hline Показники & Вище середнього & Середній & Нижче середнього \\
\hline \multicolumn{4}{|c|}{ Юнаки $(n=114)$} \\
\hline Динамометрія кистьова, кг & 18,4 & 72,0 & 9,6 \\
\hline Станова сила тулуба, кг & 11,4 & 65,8 & 22,8 \\
\hline Їндекс станової сили, \% & 14,0 & 70,2 & 15,8 \\
\hline \multicolumn{4}{|c|}{ Дівчата $(n=145)$} \\
\hline Динамометрія кистьова, кг & 8,9 & 71,8 & 19,3 \\
\hline Станова сила тулуба, кг & 10,3 & 62,8 & 26,9 \\
\hline Їндекс станової сили, \% & 12,4 & 63,5 & 24,1 \\
\hline
\end{tabular}

альні результати з віковими нормами, або оцінювати зміни, які відбуваються під впливом зовнішніх та внутрішніх фокторів.

Отримані середньогрупові результати довжини і маси тіла у юнаків та дівчат знаходяться в межах вікових норм, серед іспитованого контингенту відсутні особи 3 надлишковою масою тіла в обох статевих групах. Обхватні розміри тіла у юнаків та дівчат вказують на гармонійну статуру та відсутність будь-яких відхилень від фрізіологічної норми. Порівняльний аналіз тотальних розмірів тіла у юнаків та дівчат вказує на статистично значущу різницю $(p<0,05)$ між статевими групами, що є закономірним з огляду на їхню вікову категорію. Лише показники обхвату таза та стегна не мали статистично значущої ( $p>0,05)$ різниці між юнаками та дівчатами і знаходились майже в одному діапазоні.

Дослідження стану м'язової системи, зокрема м'язів рук і спини у студентів - майбутніх фрахівців правоохоронних органів $€$ актуальним, оскільки специфріка обраної майбутньої профеciї передбачає значні фрізичні навантаження. Відомо, що деякі елементи одягу, наприклад бронежилети, призначені для захисту від уражень вогнепальної та холодної зброї, в середньому можуть важити 8-10 кг, а маса шолома може становити 1,3-1,7 кг. В цілому загальна маса спорядження може сягати 15-20 кг. Отже, для фрахівців правоохоронних органів важливим є розвиток усіх груп м'язів.
Дослідження показників динамометрії правої та лівої кисті, а також станової сили використовували як додаткову ознаку для оцінювання рівня фрізичного розвитку. Результати, які відображають рівень розвитку сили кисті та силу м'язів хребта представлено в таблиці 2. Напруження, що супроводжується будь-якою групою м'язів, є функціональною характеристикою рухового аналізатора.

Показники динамометрії правої та лівої кисті як у юнаків, так і у дівчат мали значну варіативність, коефріцієнти варіації знаходилися в діапазонах 21,1-22,8 \%, що вказує на неоднорідність вибірки і свідчить про те що м'язовий корсет остаточно ще не сформований. У обох статевих групах спостерігається асиметричний розвиток м'язів, зазвичай сила правої кисті домінуюча. Аналіз середньогрупових результатів динамометрії правої лівої кисті у юнаків і дівчат вказує на відповідність їхнім віковим нормам. Середньогруповий показник динамометрії правої кисті у юнаків становить 42,8 кг за Ме $(25 \% ; 75 \%)=42,0$ $(40,0 ; 46,0)$, а лівої - 37,3 кг за Ме $(25 \% ; 75 \%)=38,0(32,0 ; 40,0)$. У дівчат цей показник становить 30,6 i 26,0 кг за Ме $(25 \% ; 75 \%)=26,0$ $(22,0 ; 29,0)$ відповідно. У юнаків індивідуальні значення динамометрії правої кисті знаходяться в діапазонах від мінімального 20,5 до максимального 67,5 кг, а лівої кисті - від 19,0 до 62,0 кг, у дівчат - від 23,0 до 41,0 кг правої кисті та від 15,0 до 39 кг лівої кисті.
Середньогруповий показник абсолютної станової сили у юнаків становить 136,4 кг, що відповідає середньому рівню. Максимальне значення спостерігалось в діапазоні 181,0 кг, а мінімальне - 81,0 кг. Така велика різниця у 100 кг вказує на значну варіативність даного показника. Середньогруповий показник індексу станової сили - 192,4 \% і за шкалою градації також відповідає середньому рівню.

У дівчат середньогруповий показник абсолютної станової сили становить 89,3 кг і знаходиться в діапазоні середнього рівня, а індекс станової сили - 147,2 \%, що також відповідає середньому рівню. Мінімальне значення станової сили хребта у дівчат становить 51,0 кг, а максимальне - 113,0 кг, що вказує на значну варіативність вибірки.

Розподіл юнаків і дівчат за рівнем розвитку кистьової динамометрії, станової сили хребта та індексу станової сили вказує на перевагу середнього рівня.

Вміст жирової тканини визначали методом каліперометрії за товщиною п'яти шкірно-жирових складок, а також їх суми. Відомо, що жирова тканина необхідна організму, оскільки забезпечує запас енергії вітамінів і жирних кислот, які сприяють забезпеченню життєво важливих процесів, також виконує захисну і теплоізоляційну фрункції, накопичує і синтезує деякі гормони. Але слід вказати на те, що надлишок жирової маси в організмі може спричинити численні порушення: від гормональних до проблем з опорно-руховим апаратом, серцевосудинною і дихальною системами. Результати дослідження жирової тканини юнаків і дівчат представлено в таблиці 3.

Результати досліджень п'яти шкірно-жирових складок та їх суми у юнаків вказують на значну варіативність, коесріцієнти варіації знаходяться в діапазонах 55,4-93,5 \%, що свідчить про неоднорідність вибірки. у юнаків найбільший вміст жирової маси знаходилось у складках біцепса та під лопаткою, а найменший - у складці трицепса. У дівчат усі п'ять шкірно-жирових складок, а також їх сума вища, ніж у юнаків, що є зако- 
номірним при порівнянні у даній віковій категорії. Відомо, що відсоток незамінних жирових відкладень у жінок вищий, ніж у чоловіків, що обумовлено вимогами народження дітей та іншими гормональними функціями. Результати коефіцієнтів кореляції знаходяться в діапазонах 38,2-69,7 \%, що також вказує на неоднорідність вибірки. Найбільший вміст жирової маси знаходиться у складці біцепса та внутрішній литковій, а найменший - у складці трицепса. Таку особливість розподілу жирової маси можна пояснити характером харчування.

Наступним етапом наукової роботи був аналіз композиційного складу тіла юнаків та дівчат. У наукових дослідження досить часто розглядають два-, три-, чотири- та багатокомпонентні моделі складу тіла людини. Біоімпедансний аналіз тіла дає об'єктивні дані про склад біологічних тканин конкретного індивіда і вказує на можливі відхилення і функціональні порушення в організмі. Слід зазначити, що зміни композиційного складу тіла людини відбуваються протягом усього періоду життедіяльності. Результати дослідження композиційного складу тіла юнаків та дівчат представлено в таблиці 4.

Середньогруповий показник жирової маси (ЖМ, \%) в обстежуваних юнаків відповідає віковій нормі. Оскільки жирова маса є найбільш мінливим компонентом тіла людини, індивідуальні результати у юнаків знаходились в межах від мінімального $8,7 \%$ до максимального 28,8 \%, тобто спостерігався дефіцит жирової маси у 14,0\% осіб.

Як видно з таблиці 4, у юнаків показники жирової маси та вісцерального жиру мають найвищі коефіцієнти варіації: 27,6 \% та 82,9 \%, що свідчить про неоднорідність вибірки. У дівчат середньогруповий показник ЖМ теж знаходиться в межах фрізіологічної норми. Аналіз індивідуальних показників ЖМ дав змогу виявити 11,0\% осіб $з$ дефіцитом жирової маси. Обстежувана вибірка дівчат також характеризувалася своєю неоднорідністю за показниками ЖМ та вісцерального жиру, коефіцієнти варіації знаходились у діапазонах 20,7-40,3 \%. У здорових людей індивідуальні показники вісцерального жиру в нормі знаходяться у межах 1,0-4,0\%, інтервал 5,0-8,0 \% вважається допустимим рівнем, а 9,0 \% і більше - свідчить про ожиріння. Отримані в ході дослідження середньостатистичні показни- ки вісцерального жиру у юнаків та дівчат знаходяться в межах фрізіологічної норми.

Відомо, що загальний вміст води являє собою найбільший за масою композиційний склад тіла молекулярного рівня. 3 літературних джерел ві-

Т а б л и ц я 3. Середньостатистичні показники п'яти шкірно-жирових складок юнаків та дівчат $(n=259)$

\begin{tabular}{|c|c|c|c|c|c|c|}
\hline Показники & $\bar{x}$ & S & Me & $25 \%$ & $75 \%$ & $V, \%$ \\
\hline \multicolumn{7}{|c|}{ Юнаки $(\mathrm{n}=114)$} \\
\hline Складка трицепса, мм & 6,6 & 6,15 & 4,0 & 3,0 & 7,5 & 93,5 \\
\hline Складка біцепса, мм & 13,4 & 7,40 & 12,8 & 7,3 & 18,0 & 55,4 \\
\hline Складка під лопаткою, мм & 11,7 & 5,66 & 10,0 & 8,0 & 14,0 & 48,3 \\
\hline Складка над клубовою кісткою, мм & 11,0 & 5,76 & 10,0 & 7,0 & 14,0 & 52,1 \\
\hline Внутрішня литкова складка, мм & 10,8 & 6,93 & 8,3 & 5,0 & 17,0 & 64,0 \\
\hline Сума шкірно-жирових складок, мм & 55,0 & 36,43 & 36,7 & 24,8 & 74,4 & 66,3 \\
\hline \multicolumn{7}{|c|}{ Дівчата ( $n=145)$} \\
\hline Складка трицепса, мм & 8,8 & 5,59 & 7,0 & 5,0 & 13,0 & 63,4 \\
\hline Складка біцепса, мм & 15,8 & 6,19 & 15,0 & 12,0 & 18,0 & 39,2 \\
\hline Складка під лопаткою, мм & 13,5 & 10,74 & 9,0 & 6,9 & 19,3 & 79,8 \\
\hline Складка над клубовою кісткою, мм & 12,4 & 8,67 & 6,9 & 5,0 & 23,0 & 69,7 \\
\hline Внутрішня литкова складка, мм & 15,1 & 6,23 & 14,0 & 10,0 & 20,0 & 41,2 \\
\hline Сума шкірно-жирових складок, мм & 63,2 & 24,15 & 58,0 & 46,0 & 72,0 & 38,2 \\
\hline
\end{tabular}

т а б л и ц я 4. Середньостатистичні результати композиційного складу тіла юнаків та дівчат $(n=259)$

\begin{tabular}{|c|c|c|c|c|c|c|}
\hline Показники & $\bar{x}$ & s & Me & $25 \%$ & $75 \%$ & $V, \%$ \\
\hline \multicolumn{7}{|c|}{ Юнаки $(n=114)$} \\
\hline Жирова маса, \% & 17,1 & 4,73 & 17,2 & 13,1 & 20,1 & 27,6 \\
\hline Основний обмін, ккал & 1837,1 & 263,51 & 1835,0 & 1645,0 & 1935,0 & 14,3 \\
\hline Вміст води, \% & 62,3 & 5,32 & 62,0 & 57,8 & 67,2 & 8,5 \\
\hline Вісцеральний жир, \% & 2,4 & 1,96 & 1,5 & 1,0 & 3,0 & 82,9 \\
\hline Кісткова маса, \% & 3,0 & 0,39 & 3,1 & 2,8 & 3,2 & 12,9 \\
\hline М'язова маса, \% & 58,4 & 8,16 & 58,2 & 52,1 & 63,6 & 14,0 \\
\hline \multicolumn{7}{|c|}{ Дівчата ( $n=145)$} \\
\hline Жирова маса, \% & 20,7 & 4,30 & 21,0 & 17,2 & 23,9 & 20,7 \\
\hline Основний обмін, ккал & 1326,8 & 124,82 & 1311,0 & 1264,0 & 1378,0 & 9,4 \\
\hline Вміст води, \% & 58,6 & 3,47 & 58,2 & 56,2 & 60,3 & 5,9 \\
\hline Вісцеральний жир, \% & 2,1 & 0,84 & 2,0 & 1,0 & 3,0 & 40,3 \\
\hline Кісткова маса, \% & 2,1 & 0,15 & 2,1 & 2,0 & 2,2 & 7,2 \\
\hline М'язова маса, \% & 39,8 & 3,68 & 39,5 & 37,4 & 41,8 & 9,3 \\
\hline
\end{tabular}


домо, що у здорової дорослої людини вміст води в організмі досить постійний і становить у середньому $60 \%$ маси тіла. Цей показник досить мінливий протягом усього життя, так, найбільший вміст води спостерігається у новонародженого - 70 \%, найменша кількість води у літніх людей - близько 50 \%. Як видно з таблиці 4, середньогруповий показник вмісту води у юнаків відповідає віковій нормі, у дівчат він дещо нижчий. Основна функція водного компонента в організмі людини - це забезпечення необхідних умов для здійснення обміну речовин.

Індивідуальні вікові зміни безжирової маси (кістковий та м'язовий компоненти) мають більш стійкий характер порівняно із жировим компонентом, і знаходяться у прямій залежності від генетичних факторів. У період статевого дозрівання у юнаків швидкими темпами відбувається нарощування м'язової та кісткової маси. Фізіологічна норма безжирового компонента для юнаків та чоловіків 16-39 років становить понад 70,0 \%. Індивідуальний показник безжирової маси 80,0 \% і вище зазвичай характерний для юнаків і чоловіків, які регулярно займаються фрізичними тренуваннями. Результати дослідження безжирової маси вказують на те, що середньогрупові показники м'язового та кісткового компонентів в обстежуваних юнаків знаходяться нижче фрізіологічної норми. Аналіз індивідуальних результатів вказує на значний діапазон значень м'язового компонента - від мінімального 36,1 \% до максимального 78,4 \%, це свідчить про те, що у них продовжується біологічне формування організму.

у нормі м'язовий компонент для дівчат становить 35,0-41,0\%, а $42,0 \%$ і вище - характерний для тих, хто займається фрізичними тренуваннями. Середньостатистичний показник м'язового компонента в обстежуваних дівчат знаходиться у нормі. IHдивідуальні вікові зміни без кісткового та м'язового компонента мають стійкий характер і знаходяться у прямій залежності від генетичних факторів. Середньостатистичний показник кісткового компонента у дівчат знаходиться нижче норми.
Зменшення частки м'язової та кісткової маси тіла у юнаків та дівчат може призвести до сповільнення основного обміну й порушення метаболічних процесів.

Спираючись не тільки на антропометричні дані, а й на композиційний склад тіла, біоімпедансний аналіз дає можливість вибору найбільш інфрормативних способів нормування показників загального метаболізму. Визначення показника основного обміну дає можливість скорегувати режим харчування і рухової активності. 3 літературних джерел відомо, що величина показника основного обміну прямо залежить від статі, віку, довжини маси тіла, температури тіла та інших факторів. Використовуючи антропометричні та біоелектричні параметри, можна отримати оцінку основного обміну, який характеризує енергетичний метаболізм людини. Фізіологічна норма для юнаків знаходиться в діапазоні 1800-2100 ккал на добу, а для дівчат - 1300-1700 ккал на добу. Середньогруповий результат юнаків та дівчат знаходиться в межах фрізіологічної норми. Слід також зауважити, що величина основного обміну залежить від рівня розвитку скелетно-м'язової тканини. За однакових показників маси і довжини тіла індивідуальні значення основного обміну у юнаків з атлетичною статурою на 10-15 \% вищі, ніж у юнаків з надлишковою жировою масою.

Висновки. На основі даних проведеного констатуючого етапу дослідження визначено стан показників фізичного розвитку студентів - майбутніх фахівців правоохоронної діяльності. Встановлено, що середньогрупові результати довжини і маси тіла у юнаків та дівчат знаходяться в межах вікових норм, серед обстежуваного контингенту відсутні особи 3 надлишковою масою тіла в обох статевих групах, обхватні розміри тіла у юнаків та дівчат вказують на гармонійну статуру та відсутність будь-яких відхилень від фізіологічної норми. Середньостатистичні показники вісцерального жиру знаходяться в межах фрізіологічної норми, середньогрупові показники м'язового та кісткового компонентів у юнаків та кісткового компонента у дівчат нижчі фрізіологічної норми. Отримані результати будуть використані під час розробки програми занять з ППФП.

Перспективи подальших досліджень полягають в оцінюванні показників функціонального стану та фізичної підготовленості майбутніх правоохоронців як основних компонентів для розробки програми занять професійно-прикладної спрямованості 3 використанням засобів оздоровчого фрітнесу.

Конфлікт інтересів. Автори заявляють, що відсутній будь-який конфрлікт інтересів.

\section{ЛITEPATУPA}

1. Андрєєва О. Концептуальні та прикладні аспекти технологізації проектувальної діяльності в сфрері фізичної рекреації. Теорія і методика фрізичного виховання і спорту. 2013;1:3540.

2. Андрєєва 0, Кенсицька І. Лімітуючі та стимуляційні чинники формування цінностей здорового способу життя студентів. Вісник Східноєвропейського національного університету імені Лесі Українки. 2017;26:37-42.

3. Андрєєва 0, Гресь М, Пилипей Л. Використання засобів оздоровчого фітнесу у професійно-прикладній фрізичній підготовці майбутніх фахівців правоохоронної сфери. Теорія і методика фізичного виховання і спорту, 2019;1:65-71. DOI: 10.32652/tmfvs.2019.1.65-70.

4. Благій ОЛ, Андрєєва ОВ. Рухова активність як фактор формування здорового способу життя учнівської молоді. Актуальні проблеми фізичного виховання, реабілітації, спорту та туризму: матеріали III Міжнар. наук.-практ. конф. Запоріжжя : КПУ,2011:27-28.

5. Вереньга ЮВ. Удосконалення фрізичної підготовки працівників МВС України на етапі професійного становлення [дисертація]. Львів, 2015. 262 c.

6. Еремина ЕЛ. Состояние фризического развития и уровня соматического здоровья школьников подросткового возраста в г. Полтаве. Всеукраїнська міжвузівська наук.-практ. конф. «Методичні проблеми фрізичної культури та спорту: досвід, сучасні напрямки та перспективи». Дніпропетровськ, 1999. 188 с.

7. Катерина УМ, Андрєєва ОВ. Соціальнопедагогічні передумови впровадження навчально-оздоровчих комплексів в процес фрізичного виховання студентів. Вісник Східноєвропейського національного університету ім. Лесі Українки. 2014;14:18-22.

8. Круцевич ТЮ, Андрєєва ОВ, Благій ОЛ. Проблеми організації рекреаційно-оздоровчих занять в структурі дозвільної діяльності студентської молоді. Гуманітарний вісник ДВНЗ «Переяслав-Хмельницький державний педедагогічний університет ім. Г. С. Сковороди». 2012:100-116.

9. Byshevets N, Shynkaruk 0, Stepanenko 0, Gerasymenko S, Tkachenko S, Synihovets I., Filipov V, Serhiyenko K, lakovenko O. Development skills implementation of analysis of variance at sportpedagogical and biomedical researches. Journal of 
Physical Education and Sport. 2019;19(6):20862090. DOI: 10.7752/jpes.2019.s6311

10. Byshevets N, Denysova L, Shynkaruk 0 , Serhiyenko K, Usychenko V, Stepanenko 0 , Syvash I. Using the methods of mathematical statistics in sports and educational research of masters in physical education and sport. Journal of Physical Education and Sport. 2019;19(3):1030 1034. DOI: $10.7752 /$ jpes.2019.s3148

11. Hakman A, Andrieieva O, Bezverkhnia $\mathrm{H}$, Moskalenko N, Tsybulska V, Osadchenko T, Savchuk S, Myrkovalchuk V, Filak Y. Dynamics of the physical fitness and circumference sizes of body parts as a motivation for self-improvement and self-control in students. Journal of Physical Education and Sport. 2020;20(1):116-22. DOI: 10.7752/ jpes.2020.01015

12. Hakman A, Andrieieva 0 , Kashuba V Nakonechnyi I, Cherednichenko S, Khrypko I, Tomilina Y, Filak F, Moldovan A. Characteristics of biogeometric profile of posture and quality of life of students during the process of physical education. Journal of Physical Education and Sport. 2020;20(1):79-85. DOI: 10.7752/jpes.2020.01010

13. Imas YV, Dutchak MV, Andrieieva OV, Kashuba V0, Kensytska IL, Sadovskyi 00 Modern approaches to the problem of values' formation of students' healthy lifestyle in the course of physical training. Physical Education of Students. 2018;22(4):182-9. DOI: 10.15561/20755279.2018.0403

14. Kashuba V, Kolos M, Rudnytskyi O, Yaremenko V, Shandrygos V, Dudko M, Andrieieva 0 . Modern approaches to improving body constitution of female students within physical education classes. Journal of Physical Education and Sport. 2017;17(4):2472-6. DOI: 10.7752/ jpes.2017.04277

\section{LITERATURE}

1. Andreieva O. Conceptual and applied aspects of technologicalization of design activities in the field of physical recreation. Teoriia i metodyka fizvykhovannia i sportu. 2013;1:35-40.

2. Andreieva 0, Kensytska I. Limiting and stimulating factors of formation of values of a healthy way of life of students. Visnyk Skhidnoievropeyskoho universytetu im. Lesi Ukrainky. 2017;26:37-42

3. Andreieva 0, Hres M, Pylypei L. The use of health fitness in professional and applied physical training of future law enforcement professio- nals. Teoriia i metodyka fizvykhovannia i sportu 2019:1:65-71. D0I: 10.32652/tmfvs.2019.1.65-70

4. Blahii OL, Andreieva OV. Motor activity as forming factor of healthy lifestyle of student youth. Aktualni problemy fizvykhovannia, reabilitatsii, sportu ta turyzmu: materialy III Mizhnar. nauk prakt. konferentsii. Zaporizhzhia: KPU,2011:27-28

5. Verenha IV. Improving physical training of employees of the Ministry of Internal Affairs of Ukraine at the stage of professional development [dissertation]. Lviv, 2015. 262 p.

6. Yeremina EL. The state of physica development and the level of somatic health of adolescent schoolchildren in Poltava. Vseukrainska mizhvuzivska nauk.-prakt. Konferentsiia. Dnipropetrovsk, 1999. $188 \mathrm{p}$.

7. Kateryna UM, Andreieva OV. Sociopedagogical prerequisites for the introduction of educational and health complexes in the process of physical education of students. Visnyk Skhidnoievropeyskoho universytetu im. Lesi Ukrainky. 2014:14:18-22

8. Krutsevych TI, Andreieva OV, Blahii OL. Problems of organization of recreational and health-improving classes in the structure of leisure activities of student youth. Humanitarnyi visnyk DVNZ «Pereiaslav-Khmelnytskyi pedahohichnyi universytet im. H. S. Skovorody». 2012:100-116.

9. Byshevets N, Shynkaruk 0, Stepanenko O Gerasymenko S, Tkachenko S, Synihovets I., Filipov V, Serhivenko K, lakovenko 0. Development skills implementation of analysis of variance at sportpedagogical and biomedical researches. Journal of Physical Education and Sport. 2019;19(6):20862090. DOI: 10.7752/jpes.2019.s6311

10. Byshevets N, Denysova L, Shynkaruk O Serhiyenko K, Usychenko V, Stepanenko O,
Syvash I. Using the methods of mathematical statistics in sports and educational research of masters in physical education and sport. Journal of Physical Education and Sport. 2019;19(3):10301034. DOI: 10.7752/jpes.2019.s3148

11. Hakman A, Andrieieva O, Bezverkhnia $\mathrm{H}$ Moskalenko N, Tsybulska V, Osadchenko T, Savchuk S, Myrkovalchuk V, Filak Y. Dynamics of the physical fitness and circumference sizes of body parts as a motivation for self-improvement and self-control in students. Journal of Physical Education and Sport. 2020;20(1):116-22. DOI: 10.7752/ jpes.2020.01015

12. Hakman A, Andrieieva O, Kashuba V, Nakonechnyi I, Cherednichenko S, Khrypko I, Tomilina $Y$, Filak F, Moldovan A. Characteristics of biogeometric profile of posture and quality of life of students during the process of physical education. Journal of Physical Education and Sport 2020:20(1):79-85. DOl: 10.7752/jpes.2020.01010

13. Imas YV, Dutchak MV, Andrieieva OV, Kashuba VO, Kensytska IL, Sadovskyi 00. Modern approaches to the problem of values' formation of students' healthy lifestyle in the course of physical training. Physical Education of Students. 2018;22(4):182-9 DOI:10.15561/20755279.2018.0403

14. Kashuba V, Kolos M, Rudnytskyi 0 Yaremenko V, Shandrygos V, Dudko M, Andrieieva 0 . Modern approaches to improving body constitution of female students within physical education classes. Journal of Physical Education and Sport. 2017;17(4):2472-6. DOI: 10.7752 jpes.2017.04277

Надійшла 25.12.2020

\section{ІНФОРМАЦІЯ ПРО АВТОРІВ}

Гресь Марина https://orcid.org/0000-0002-5459-5236, gres.marina.95@ukr.net Пацалюк Костянтин Григорович https://orcid.org/0000-0002-3581-443X, K.patsaliuk@gmail. com

Національний університет фізичного виховання і спорту України 03150, Київ, вул. Фізкультури, 1

\section{INFORMATION ABOUT THE AUTHORS}

Hres Maryna https://orcid.org/0000-0002-5459-5236, gres.marina.95@ukr.net Patsaliuk Kostiantyn https://orcid.org/0000-0002-3581-443X, K.patsaliuk@gmail.com

National University of Ukraine on Physical Education and Sport 03150, Kyiv, Fizkul'tury str., 1 